\title{
Studi Komparasi Hak Waris dalam Hukum Adat dan Islam di Masyarakat Madura Perantauan Desa Jelbuk, Kecamatan Jelbuk, Kabupaten Jember
}

\author{
Nur Nafa Maulida Atlanta \\ University of Jember, Indonesia \\ nurnafafhunej@gmail.com
}

\section{Dominikus Rato}

University of Jember, Indonesia

dominikusrato@gmail.com

\section{Emi Zulaika}

University of Jember, Indonesia

emizulaika@ymail.com

\begin{abstract}
The rules of inheritance customary law are legal norms that regulate how the objects or inheritance are distributed to heirs from generation to generation. Each region is inseparable from the influence of different kinship arrangements, including patrilineal, matrilineal, parental or bilateral. The heterogeneous village of Jelbuk has indigenous tribes, namely the indigenous Jelbuk tribe who was born and settled in Jelbuk Village and the majority are Madurese. In addition, there are migrated Madurese people, where the indigenous Madurese bond with the Jelbuk people so that they finally decide to stay and do inheritance so that the interesting thing to research is the inheritance system and parts of boys and girls. This paper uses an empirical juridical method with the case approach of written customary law (socio-legal) and comparative approach.
\end{abstract}

KEYWORDS: Inheritance, Customary Law, Migrated Madurese.

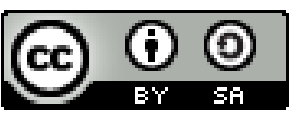

Copyright $₫ 2018$ by Author(s)

This work is licensed under a Creative Commons Attribution-ShareAlike 4.0 International License. All writings published in this journal are personal views of the authors and do not represent the views of this journal and the author's affiliated institutions.

\section{HOW TO CITE:}

Atlanta, Nur Nafa Maulida, Dominikus Rato \& Emi Zulaika. "Studi Komparasi Hak Waris dalam Hukum Adat dan Islam di Masyarakat Madura Perantauan Desa Jelbuk, Kecamatan Jelbuk, Kabupaten Jember" (2018) 5:3 Lentera Hukum 431-448.

Submitted: July 30, 2018 Revised: August 02, 2018 Accepted: Auguts 30, 2018 


\section{PENDAHULUAN}

Indonesia mengenal tiga jenis struktur sosial sebagai organisasi sosial kemasyarakatan yang dalam hukum adat disebut sistem kekerabatan, yaitu matrilineal, patrilineal, dan parental. Yang membedakan antara ketiga jenis strukrur tersebut yaitu kedudukan anak laki-laki dan anak perempuan dalam penerimaan warisan yang diterimanya sebagai ahli waris. Apabila orang tua telah meninggal dunia, maka harta yang dimilikinya secara otomatis turun menjadi hak daripada anaknya sebagai pewaris dengan bagian tertentu di mana setiap daerah berbeda dalam sistem pewarisannya. Beberapa daerah di Indonesia memiliki sistem pewarisan adat yang masih berpegang teguh oleh masyarakatnya yaitu sistem kewarisan individual memberikan harta warisan secara perorangan kepada ahli waris seperti di Jawa dan Madura.

Kehidupan dalam masyarakat adat sangat erat dengan sistem kekeluargaan dan kekerabatan. Dengan demikian, tidak menutup kemungkinan menimbulkan permasalahan yang berkaitan dengan kepentingan pribadi seperti permasalahan pembagian tanah warisan, yang sering kali menimbulkan perselisihan dalam lingkungan keluarga. ${ }^{1}$ Masyarakat adat yaitu kesatuan masyarakat yang teratur dan tetap di mana anggotanya tidak hanya terikat pada suatu kediaman atau wilayah daerah tertentu. Baik berkaitan dengan hal duniawi sebagai tempat kehidupan maupun dalam berkaitan rohani sebagai tempat pemujaan terhadap roh-roh leluhur (teritorial). Akan tetapi, terikat hubungan keturunan dalam ikatan pertalian sedarah atau kekerabatan yang sama dari satu leluhur, secara langsung atau tidak langsung karena suatu pertalian perkawinan atau adat (genealogis). ${ }^{2}$

Di Desa Jelbuk terdapat masyarakat Madura yang merantau di Jawa khususnya di Desa Jelbuk, Kecamatan Jelbuk, Kabupaten Jember yang biasa disebut Madura Perantauan. Di mana masyarakat asli Madura tersebut melakukan ikatan perkawinan dengan warga Jelbuk yang pada akhirnya memutuskan untuk tinggal dan menetap di Desa Jelbuk dan melakukan pembagian warisan. Berdasarkan hal tersebut, permasalahan di Desa Jelbuk mengenai pewarisan belum ada pihak-pihak yang melakukan penelitian mengenai hal tersebut. Di samping itu, masyarakat di Desa Jelbuk tergolong masyarakat heterogen yang berbeda suku dan keturunan serta mendiami Desa Jelbuk.

Berdasarkan pembahasan di atas, terdapat isu hukum yang menarik untuk diteliti yaitu masyarakat Madura Perantauan, karena setiap daerah memiliki adat istiadat tersendiri apakah hal tersebut memiliki perbedaan atau persamaan dengan adat istiadat setempat.

1 Ahmad Ibrahim, Menyelesaikan Sengketa Pembagian Harta Warisan Melalui Peran Kepala Desa, Jurnal Hukum,Universitas Gorontalo, 2010, hlm. 1.

2 Hilman Hadikusuma, Pengantar Ilmu Hukum Adat Indonesia, (Bandung: CV Mandar Maju, 2003), hlm. $108-109$. 


\section{PERBANDINGAN SISTEM PEWARISAN MENURUT HUKUMADAT DAN ISLAM PADA MASYARAKAT MADURA DAN MADURA PERANTAUAN}

Dalam pembahasan kali ini, untuk melihat bagaimana perbandingan sistem perwarisan menurut hukum adat pada masyarakat Madura Perantauan di Desa Jelbuk dengan sistem pewarisan Hukum Adat di Madura. Berangkat dari rumusan masalah tersebut, perlu diketahui terlebih dahulu mengenai Madura dan masyarakatnya. Madura adalah nama pulau yang terletak di sebelah Timur Laut Jawa Timur yang besarnya kurang lebih 5.168 kilometer persegi. yang dihuni oleh hampir 4.000.000 penduduk. Pulau Madura terdiri dari empat kabupaten, yaitu Bangkalan, Sampang, Pamekasan dan Sumenep. ${ }^{3}$ Berdasarkan hal tersebut, penelitian ini akan fokus mengkaji tentang pembagian waris dalam lingkup keluarga di dalam masyarakat Madura. Penelitian dilakukan di Desa Potoan Daya, Kecamatan Palengaan, Kabupaten Pamekasan untuk mengetahui sistem pewarisan hukum adat Madura pada daerah setempat, dan masyarakat Madura Perantauan Desa Jelbuk untuk mengetahui sistem pewarisan menurut hukum adat Madura Perantauan.

Desa Potoan Daya dengan jumlah penduduk mayoritas masyarakat berprofesi sebagai petani dan semua penduduk desa ini menganut agama Islam yang ditunjang dengan adanya sebuah Pondok Pesantren Banyu Anyar yang terbesar di daerah Pamekasan. Agama Islam sudah meresap dan mewarnai pola kehidupan sosial mereka seperti budaya maupun perilaku yang memiliki pengaruh yang sangat kental dalam kehidupan sehari-hari. Islam merupakan salah satu sifat yang mendefinisikan bahwa semua orang Madura pasti beragama Islam sehingga dalam masyarakat Madura saat ini sangat kental dengan budaya dan agama Islam. Islam di Madura mempengaruhi pola hidup di dalam masyarakat seperti perilaku maupun kebiasaan. Dalam hal perkawinan maupun perwarisan, hal ini berpengaruh terhadap penyelesaian sengketa di antara masyarakat dalam berbagai aspek. Perbandingan sistem pewarisan antara Desa Potoan Daya dengan masyarakat Madura Perantauan Desa Jelbuk dilakukan untuk mengetahui sistem pewarisan menurut hukum adat Madura Perantauan sebagai berikut:

\begin{tabular}{|c|c|c|c|}
\hline No. & Aspek & $\begin{array}{c}\text { Masyarakat Madura } \\
\text { Perantauan di Desa Jelbuk }\end{array}$ & $\begin{array}{c}\text { Masyarakat Madura di Desa } \\
\text { Poto'an Daya }\end{array}$ \\
\hline 1. & Ahli Waris & Anak laki-laki dan perempuan & Anak laki-laki dan perempuan \\
\hline 2. & $\begin{array}{l}\text { Proses } \\
\text { Pewarisan }\end{array}$ & 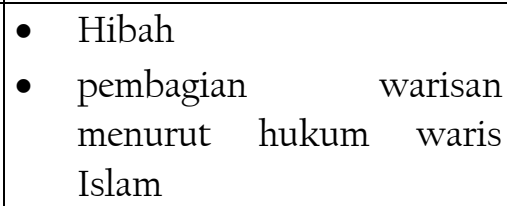 & $\begin{array}{ll} & \text { Hibah } \\
- & \text { pembagian warisan menurut } \\
& \text { hukum waris Islam }\end{array}$ \\
\hline 3. & $\begin{array}{l}\text { Jumlah bagian } \\
\text { ahli waris }\end{array}$ & 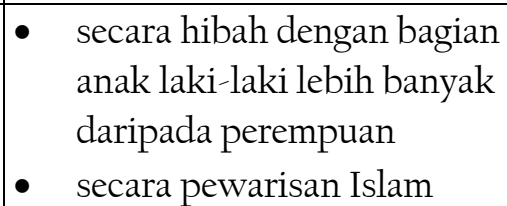 & 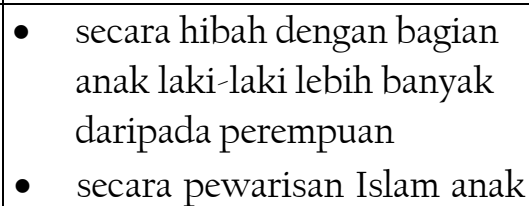 \\
\hline
\end{tabular}

Kutwa Fath et.al., Pamekasan dalam Sejarah, (Pamekasan: Pemerintah Kabupaten Pamekasan, 2006), hlm. 14. 


\begin{tabular}{|c|c|c|c|}
\hline & & $\begin{array}{l}\text { anak laki-laki dan } \\
\text { perempuan mendapatkan } \\
\text { bagian } 2: 1\end{array}$ & $\begin{array}{l}\text { laki-laki dan perempuan } \\
\text { mendapatkan bagian } 2: 1\end{array}$ \\
\hline 4. & Harta Warisan & $\begin{array}{l}\text { Berupa: } \\
\text { - } \text { tanah } \\
\text { - rumah } \\
\text { - } \text { pekarangan } \\
\text { - } \text { mobil atau benda bergerak } \\
\text { lainnya } \\
\text { - dan lain-lain }\end{array}$ & $\begin{array}{l}\text { Berupa: } \\
\text { - } \quad \text { tanah } \\
\text { - } \quad \text { rumah } \\
\text { - } \quad \text { ternak } \\
\text { - } \quad \text { sawah } \\
\text { - } \quad \text { dan lain-lain }\end{array}$ \\
\hline 5. & $\begin{array}{l}\text { Pola } \\
\text { Penyelesaian } \\
\text { Sengketa }\end{array}$ & $\begin{array}{l}\text { Pola penyelesaian dilakukan } \\
\text { dengan musyarawah antar } \\
\text { pewaris, apabila tidak selesai } \\
\text { maka diselesaikan di kantor } \\
\text { desa. }\end{array}$ & $\begin{array}{l}\text { Pola penyelesaian dengan cara } \\
\text { mediasi dan melibatkan tokoh } \\
\text { agama/ ulama dan pemerintah } \\
\text { (desa) }\end{array}$ \\
\hline
\end{tabular}

Tabel 1 : Perbandingan sistem pewarisan di Desa Jelbuk dan Madura

Berdasarkan tabel di atas, secara umum pewarisan tersebut merupakan pewarisan secara parental atau bilateral (garis keturunan bapak dan ibu). Namun, pewarisan terhadap anak laki-laki dan anak perempuan tidaklah sama. Di Desa Potoan Daya dan masyarakat Madura Perantauan di Desa Jelbuk, sistem pewarisan kedua daerah tersebut adalah sama, di mana bagian anak laki-laki lebih besar daripada bagian anak perempuan. Hal tersebut dikarenakan seorang anak laki-laki memiliki tanggung jawab yang besar di dalam keluarga karena sebagai pengganti orang tua menjadi kepala keluarga. Sehingga semua keperluan di dalam keluarga dalam mengelola dan mengambil sebuah keputusan ada pada dirinya kelak atau disebut denganistilah "mekolnyo'on" atau memikul-memanggul di atas kepala. Sedangkan anak perempuan hanya "nyo'on" saja, walaupun pewaris memiliki anak laki-laki dan anak perempuan, tetap bagian anak laki-laki lebih banyak. Namun pada masyarakat Patoan Daya, rumah diberikan kepada anak perempuan karena sebagai tempat berpulangnya "pamolean" sanak saudara atau kerabat lainnya. Begitupun pada masyarakat Madura Perantauan di Desa Jelbuk.

Masyarakat di Desa Potoan Daya sangat memegang teguh aturan agama Islam sehingga dalam pembagian warisan mengikuti aturan waris Islam yaitu bagian anak laki-laki dan anak perempuan mendapatkan bagian dengan perbandingan 2:1. Sebagaimana pembagian harta warisan adat Madura secara umum didahului dengan pemberian hibah pada ahli waris tertentu yaitu anak kandung. Apabila terjadi adanya ketidaksetujuan dari ahli waris maka pemberian hibah tersebut akan ditambahkan dengan harta warisan yang akan dibagikan kepada ahli waris. Dalam hal penentuan ahli waris, sebagian besar masyarakat Pamekasan tidak memberikan bagian kepada kelompok ahli waris lain selain anak-anak. Hal ini dikarenakan masyarakat Pamekasan menganggap bahwa yang dilakukannya adalah sesuai dengan tradisi dan budaya 
mereka. Apabila orang tua tidak pernah mengharapkan harta dari anak-anak, meskipun kadang-kadang sampai harus hidup di tempat yang tidak layak karena hartanya sudah dialihkan kepada anak-anaknya, terhadap ahli waris janda atau duda juga ada sebagian masyarakat yang tidak memberi bagian, terutama jika bentuk tirkahnya berasal dari harta bawaan salah satu pihak suami atau istri.

Menurut M.Rofi Uddin, seorang Kepala Desa Potoan Daya ${ }^{4}$ mengatakan bahwa hukum waris yang berlaku di Desa Potoan Daya menggunakan pola Islam yang di mana anak laki-laki dan perempuan memiliki hak atas harta peninggalan orang tuanya. Secara kebiasaan belum menemukan pembagian warisan secara adat, akan tetapi dalam tradisi membagi harta masyarakat lebih cenderung secara hibah yaitu dibagi pada saat sebelum pewaris meninggal "engkok mon mateh, anak A begiannah ariah.... anak B begiannah ariah....". Di mana hukum adat tercerabut ketika Islamisasi, agama Islam masuk ke wilayah Madura sehingga berpengaruh terhadap pembagian warisan yang diyakini dan dipraktekkan oleh masyarakat, dan berkolaborasi antara budaya dan agama Islam. Selama ini orang Madura memiliki filosofi yang dipertahankan yaitu "bhuppa'atau bapak, bhabbu'atau ibu, ghuru atau guru, rato atau raja". Sebagaimana banyak ditafsirkan, figur panutan dan loyalitas utama orang Madura pertama adalah kepada kedua orang tua, kemudian kepada ghuru atau ulama/kya'i dan terakhir kepada raja (pemerintah). ${ }^{5}$ Namun ungkapan ini tidak sekedar mencerminkan figur-figur panutan dan loyalitas orang Madura, melainkan lebih daripada itu tersirat makna-makna filosofis-religius yang sangat dalam.

Hukum kewarisan Islam dikenal sebagai asas keadilan berimbang, yakni keseimbangan antara hak yang diperoleh dengan keperluan dan kegunaan dalam melaksanakan kewajiban. Dalam hukum kewarisan Islam ditemukan adanya prinsip dua berbanding satu, artinya anak laki-laki mendapatkan bagian dua kali bagian anak perempuan. Ditinjau dari segi jumlah bagian yang diperoleh saat menerima hak, memang terdapat ketidaksamaan. Akan tetapi, hal tersebut bukan berarti tidak adil, karena keadilan dalam pandangan Islam tidak hanya diukur dengan jumlah yang didapat saat menerima hak waris tetapi juga dikaitkan kepada kegunaan dan kebutuhan. Secara umum, dapat dikatakan bahwa laki-laki membutuhkan lebih banyak materi daripada perempuan. Hal tersebut dikarenakan laki-laki dalam ajaran Islam memikul kewajiban ganda yaitu untuk dirinya sendiri dan terhadap keluarganya termasuk para wanita. Jadi, standar keadilan yang mutlak adalah keadilan dengan dasar agama, yaitu keadilan yang berimbang dan bukan keadilan yang merata.

Hukum kewarisan adat dikenal sebagai asas musyawarah dan mufakat, yaitu para ahli waris membagi harta warisannya melalui musyawarah yang dipimpin oleh ahli waris yang dituakan. Apabila terjadi kesepakatan dalam pembagian harta warisan, kesepakatan itu bersifat tulus ikhlas yang dikemukakan dengan perkataan yang baik dan keluar dari hati nurani pada setiap ahli waris. Pembagian itu diselenggarakan

Hasil observasi dengan narasumber Bapak M.Rofi Uddin Kepala Desa Potoan Daya Kecamatan Palengaan Kabupaten Pamekasan pada tanggal 14 Mei 2018.

5 Latief Wiyata, Mencari Madura, (Jakarta: Bidik-Phonesis Publishing, 2013), hlm. 50. 
dengan asas kerukunan dan kemufakatan oleh kehendak bersama ahli waris dengan suasana ramah-tamah dengan memperhatikan keadaan istimewa dari tiap ahli waris. Biasanya pembagian itu dengan sepengetahuan semua anak laki-laki dan anak perempuan. Dalam hukum kewarisan Islam, dikenal asas akibat kematian, artinya kewarisan ada jika pewaris telah meninggal dunia. Sedangkan, dalam hukum kewarisan adat, faktor telah meninggalnya pewaris dan masih hidupnya ahli waris yang menjadi syarat dalam pewarisan Islam, tidaklah penting. ${ }^{6}$

Sebagaimana dalam hukum Islam, ahli waris ditentukan berdasarkan hubungan nasab dan perkawinan, sementara hukum adat lebih mengutamakan adanya hubungan nasab. Di samping itu, pembagian waris Islam cenderung meluas atau merangkul sebanyak mungkin ahli waris, sedangkan pembagian waris menurut hukum adat cenderung lebih limitatif karena adanya prinsip saling menutup antara para pihak yang potensial sebagai ahli waris. ${ }^{7}$ Menurut Bapak Abd Rachem, bahwa sistem kepercayaan pada masyarakat Desa Potoan Daya menganut agama Islam di mana sesepuh apabila ada masalah, tokoh-tokoh masyarakat turun untuk menyelesaikan masalah. Apabila ada salah satu keluarga kurang adil dalam pembagian warisan secara agama Islam sehingga sesepuh dan tokoh ulama turun tangan, walaupun sudah ditunjuk bagiannya masih ada perselisihan atau konflik. Di samping itu, masalah yang sering terjadi diantaranya adalah masalah warisan dan perempuan. Pertama, konflik warisan masih bisa diselesaikan secara kekeluargaan antara orang tua dan anak beserta keluarga lainnya. Apabila secara kekeluargaan belum ada penyelesaian, maka dan tokoh masyarakat (kyai) serta perangkat desa turun tangan untuk menyelesaikan, karena jika menggugat dianggap kurang etis di dalam lingkungan masyarakat.

Kedua, masalah perempuan, di mana seseorang laki-laki membawa kabur anak perempuan atau merebut istri orang lain maka terjadi pertengkaran fisik yaitu carok. Pelaku tersebut akan dikejar dimanapun ia berada dan pasti dibunuh (epamareh) di bumi madura ataupun di daerah perantauan. Pepatah etambang pote mata lebih bagus pote tolangi yang berarti daripada hidup menanggung malu, mending mati berkalang tanah, adalah pepatah yang paling dikenal masyarakat Madura, karena pepatah ini erat kaitannya dengan tradisi carok. Carok adalah sebuah pembelaan harga diri ketika diinjak-injak oleh orang lain, yang berhubungan dengan harta, tahta dan wanita. Carok justru dinilai sebagai suatu tindakan keji dan bertentangan dengan ajaran agama meski suku Madura sendiri kental dengan agama Islam. ${ }^{8}$

Aturan main dalam pembagian warisan bersifat rahasia sesuai dengan keluarga masing-masing. Apabila dalam keluarga dalam membagi tidak bisa secara langsung atau menunjuk harta warisannya maka acuannya minta tolong ke tokoh masyarakat atau tokoh agama yaitu kyai. Berikut merupakan skema pembagian warisan.

6 Akhmad Haries, Analisis tentang Studi Komparatif antara Hukum Kewarisan Islam dan Hukum Kewarisan Adat, Jurnal Hukum, (Samarinda: STAIN Samarinda, Vol 6 No 2, 2014 ), hlm. 226.

7 Agus Sudaryanto, Aspek Ontologi Pembagian Waris dalam Hukum Islam dan Hukum Adat Jawa, Jurnal Hukum, (Mimbar Hukum, Volume 22, Nomor 3, 2010), hlm. 541.

8 Krishna Henry Arianto, Tradisi Carok pada Masyarakat Adat Madura, http://www.esaunggul.ac.id, Diakses pada tanggal 26 Mei 2018 Pukul 15.00 WIB. 


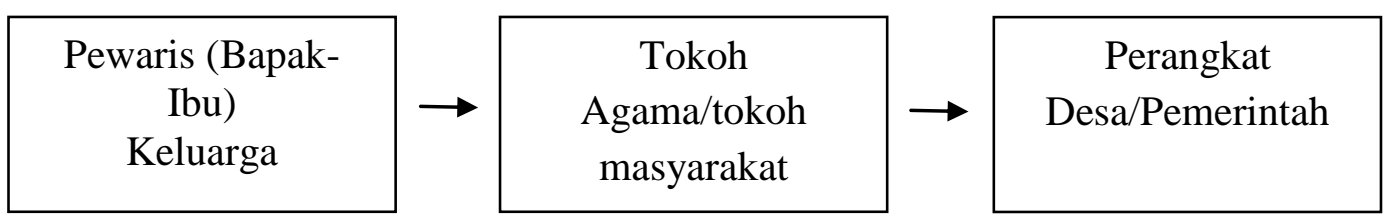

Skema 1: Alur pembagian warisan

Berdasarkan skema di atas, dapat diambil contoh dari alur pembagian warisan tersebut. Misal salah satu orang telah merantau ternyata menggugat karena tidak mendapatkan haknya karena dia adalah anaknya. Ini harus dilihat beberapa faktor. Pertama, faktor masih terjalin komunikasi atau tidak. Apabila tidak ada komunikasi dengan keluarga tetapi pada saat orang tuanya meninggal ia datang. Akan tetapi, saudara yang merawat digugat karena mendapatkan harta warisannya sedangkan ia tidak. Oleh karena itu, apabila tidak menjalin komunikasi dengan baik dengan keluarga biasanya dianggap tidak pernah ingat dengan keluarga maka akibatnya ia tidak akan mendapatkan warisan dari orang tuanya tersebut. Kedua, faktor lingkungan. Apabila lingkungan sekitar tidak setuju apabila ia mendapatkan warisan maka ia akan tetap tidak akan mendapatkan warisannya ini bentuk sanksi dari lingkungan keluarga dan masyarakat sekitar. Apabila ia tidak menggugat berarti sadar mengenai keadaan orang tuanya disamping juga ia tidak merawat ketika orang tuanya sekarat, jika menggugat berarti tega meminta harta warisan.

Apabila seseorang melakukan proses hukum, hal ini dianggap bertolak belakang dengan adat setempat, tidak menghormati atau melangkahi tokoh masyarakat (kyai). Bentuk harta warisan yang berupa benda bergerak dan benda tidak bergerak, di mana benda tidak bergerak menjadi dasarnya perselisihan antara para ahli waris karena secara pembukuan dan administrasi masih lemah dengan tidak adanya sertifikat tanah. Sehingga timbul pihak-pihak yang berkepentingan menimbulkan permasalahan, jika ada salah satu anak bercocok tanam di tanah tersebut maka secara otomatis menjadi haknya atau bagiannya sebagai ahli waris. Hal seperti itu sering menjadi konflik, seperti bagian A mendapatkan tanah di atas gunung dan B mendapatkan tanah di pinggir jalan, antara A dan B saling gugat padahal sebelumnya sudah dibagi. Konflik antar keluarga ini mengakibatkan saling mengancam antar kedua belah pihak.

Penyelesaian konflik yang melibatkan tokoh agama atau tokoh masyarakat sebagai penengah dengan cara tokoh tersebut membeli tanah yang disengketakan dan dijadikan lembaga pendidikan seperti TK dan orang yang bersengketa tadi menjadi pengurus lembaga tersebut. Adat atau tradisi lama masih dijaga agar tidak tergerus arus modern, karena kebiasaan atau adat istiadat meminimalisir gugatan secara hukum. Di samping itu, jika pewaris tidak memiliki anak maka harta warisannya jatuh kepada istri dan sebaliknya. Sebelum orang tua meninggal, anaknya dipanggil satu-persatu untuk dibagikan harta warisannya. Untuk "patobin" (rumah utama) diberikan anak mahkota yaitu lebih yang lebih dekat dengan orang tua seperti mendampingi atau 
membantu usaha pertanian dan sebagai pengganti orang tua sebagai kepala keluarga untuk mengurus semua kebutuhan.

Laura Nader dan Todd, ${ }^{9}$ mengemukakan pandangan mengenai adanya tiga fase dalam sengketa, yaitu tahap pra-konflik, tahap konflik, dan tahap sengketa. Tahap prakonflik mengacu kepada keadaan atau kondisi di mana seseorang atau kelompok merasakan adanya ketidakadilan, dan mengadakan keluhan. Tahap konflik yaitu keadaan dimana para pihak menyadari atau mengetahui tentang adanya perasaan tidak puas tersebut dan pihak yang merasa dirugikan memberitahukan keluhannya kepada pihak yang dianggap melanggar haknya. Tahap sengketa adalah keadaan dimana konflik tersebut dinyatakan di muka umum atau dengan melibatkan pihak ketiga.

\section{SISTEM PEWARISAN DALAM HUKUM ADAT DI MASYARAKAT MADURA PERANTAUAN DI DESA JELBUK}

Desa Jelbuk terdapat warga yang bersuku asli yaitu suku adat Jelbuk dan mayoritas bersuku Madura. Selain itu, terdapat masyarakat Madura yang merantau atau berimigrasi di Jawa khususnya di Desa Jelbuk yang biasa disebut Madura Perantauan. Di mana masyarakat asli Madura tersebut melakukan ikatan perkawinan dengan warga Jelbuk sehingga akhirnya memutuskan untuk tinggal dan menetap di Desa Jelbuk dan melakukan pembagian warisan. Dengan kondisi masyarakat Desa Jelbuk yang heterogen sehingga objek penelitian ini terfokus pada masyarakat Madura Perantauan. Hal ini dikarenakan adat istiadat setiap daerah berbeda dari daerah yang lain sehingga adat istiadat masyarakat Madura Perantauan yang memiliki adat istiadat tersendiri apakah memiliki perbedaan atau persamaan dengan adat istiadat setempat.

Adapun motivasi orang madura merantau ada dua faktor utama yaitu ekonomi dan sosial, artinya, hampir dapat dipastikan tujuan orang Madura merantau untuk meningkatkan taraf hidup yang pada gilirannya akan diperoleh suatu peningkatan status sosial. Sebagai perantau, mau tidak mau mereka dituntut dapat membangun interaksi sosial dengan penduduk lokal. Kehidupan sosial perantau Madura memiliki unsur-unsur primodial yaitu geneologi dan kekerabatan, sistem kepercayaan, bahasa atau dialek serta kebiasaan-kebiasaan lainnya yang akan menjadi ciri tersendiri dalam perantauan. Sistem interaksi sosial, perilaku budaya perantauan Madura akan mengalami "perbenturan" atau "persinggungan" dengan unsur-unsur primodial penduduk lokal sebagai penanda ciri dan karakter mereka. Konteks ini, perantau Madura dalam membangun interaksi sosial dengan penduduk lokal akan menghadapi paling tidak tiga alternatif kemungkinan strategi kultural, diantaranya a) tetap mempertahankan identitas etnik, b) adaptif yaitu tetap mempertahankan identitas etnik, namun pada saat yang bersamaan mulai masuk dalam identitas etnik lokal dan c) eskapistik atau melucuti identitas etnik. ${ }^{10}$

\footnotetext{
9 Putri Kurnia Sari, Pembagian Warisan dalam Budaya Poligini (Studi Kasus pada Komunitas Madura di Boto Putih, Surabaya), Jurnal Hukum, (Surabaya: Unair, Vol.1 No.1, 2012), hlm. 44.

10 Latief Wiyata, supra note 5, hlm. 46-47.
} 
Dilihat dari faktor agama, hampir dapat dipastikan semua perantau Madura memilih alternatif strategi tetapi mempertahankan agamanya selama hidup di perantauan. Perspektif antropologis, bagi orang Madura, agama Islam bukan saja sebagai referensi dalam berpikir, bersikap, bertindak dan berperilaku yang bersumber dari nilai-nilai Ilahiyah, melainkan sudah demikian melekat sebagai salah satu elemen terpenting identitas etnik. Relasi antara agama Islam dan identitas etnik orang Madura sangat kuat sehingga merupakan suatu kejanggalan, jika orang Madura menganut agama lain selain Islam. Apabila hal ini terjadi, secara ekstrim biasanya yang bersangkutan akan dianggap sebagai "bukan orang Madura" lagi. ${ }^{\text {ll }}$

Sebagaimana diketahui bahwa dalam hukum adat dikenal tiga sistem kekeluargaan yang hal ini dapat mempenaruhi pembagian harta warisan. Pembagian warisan erat kaitannya dengan bentuk masyarakat. Inilah yang menjadi salah satu penyebab adanya keanekaragaman sistem hukum kewarisan dalam hukum waris adat. Sehingga hukum kewarisan yang merupakan salah satu bagian dari sistem kekeluargaan berpangkal pada sistem garis keturunan yang pada pokoknya dikenal dengan tiga macam sistem hukum, yaitu sistem patrilineal, matrilineal, dan parental.

Hukum warisan parental atau bilateral adalah memberikan hak yag sama antara pihak laki-laki dan pihak perempuan, baik kepada suami dan istri, serta anak laki-laki dan anak perempuan termasuk keluarga dari pihak laki-laki dan keluarga pihak perempuan. Hal ini berarti bahwa anak laki-laki dan anak perempuan adalah samasama mendapatkan hak warisan dari kedua orang tuanya. Bahkan duda dan janda dalam perkembangannya juga termasuk saling mewarisi. Proses pemberian harta kepada ahli waris khususnya kepada anak, baik kepada anak laki-laki maupun anak perempuan umumnya telah dimulai sebelum orang tua atau pewaris masih hidup. Adapun sistem pembagian harta warisan dalam masyarakat ini adalah individual artinya bahwa harta peninggalan dapat dibagi-bagikan dari pemiliknya atau pewaris kepada para ahli warisnya dan dimiliki secara pribadi. ${ }^{12}$

Tidak ada aturan yang jelas mengenai pembagian warisan yang timbul dalam hukum waris adat karena adat merupakan aturan yang tidak tertulis yang timbul dari kebiasaan daerah setempat. Dengan demikian, untuk sistem kewarisan dalam hukum waris adat dipengaruhi oleh sistem kekeluargaan yang dianut oleh masing-masing daerah. Pada masyarakat Madura Perantauan di Desa Jelbuk menganut sistem kewarisan individual karena setiap anak baik laki-laki dan perempuan berhak untuk mendapatkan warisan dari kedua orang tuanya dengan sistem kekerabatan parental karena ahli waris mendapatkan harta warisan melalui garis bapak maupun ibu.

Pewarisan dengan sistem individual atau perseorangan adalah sistem pewarisan di mana setiap ahli waris mendapatkan bagian untuk dapat menguasai atau memiliki harta warisan menurut bagiannya masing-masing. Setelah harta warisan itu dibagi, maka masing-masing ahli waris dapat menguasai dan memiliki bagian harta warisannya

11 Ibid.

12 Komari, Eksistensi Hukum Waris di Indonesia: antara Adat dan Syariat, Jurnal Hukum, (Mahkamah Agung Republik Indonesia Vol. 17 No. 2, 2015), hlm. 165. 
untuk diusahakan, dinikmati maupun dijual kepada sesama ahli waris, anggota kerabat, tetangga ataupun orang lain. ${ }^{13}$ Sistem ini banyak berlaku di kalangan sistem kekerabatan parental atau di kalangan masyarakat yang kuat dipengaruhi hukum Islam. Adapun faktor yang menyebabkan pembagian sistem individual ini dilakukan, yaitu karena tidak ada lagi yang ingin memiliki harta secara bersama. Dari uraian tersebut dapat dikatakan bahwa hukum waris adat didasarkan pada sistem kekeluargaan yang ada dan terdapat beberapa asas yang mendasari adanya pembagian harta warisan yaitu asas manfaat, asas pembagian mutlak dan asas kepatuhan.

Dalam suatu pewarisan, salah satu hal terpenting yaitu adanya harta warisan. Harta warisan adalah harta milik pewaris yang dibagi-bagikan kepada ahli waris dapat berupa harta benda yang berwujud dan yang tidak berwujud. Berwujud benda, misalnya sebidang tanah, bangunan, pakaian, dan lain-lain. Kaitan harta warisan ini sebaiknya antara harta warisan dan harta peninggalan diadakan pembedaan. Untuk harta kekayaan yang siap dibagi habis dapat disebut sebagai harta warisan, sedangkan harta lain yang penerusannya tidak terbagi dapat disebutkan sebagai harta peninggalan. Harta waris dapat diuraikan lagi, diantaranya ${ }^{14}$ harta warisan, harta asal, harta peninggalan, harta pusaka dan harta perkawinan.

\section{BAGIAN ANAK LAKI-LAKI DAN PEREMPUAN MENURUT HUKUM ADAT MADURA PERANTAUAN}

Secara umum dalam masyarakat hukum adat keberadaan anak sangat penting dan berarti, diantaranya sebagai penerus keturunan, sebagai ahli waris, untuk mendoakan orang tua jika kelak meninggal dunia, sebagai pemersatu keluarga dan untuk meningkatkan status sosial. Sebagaimana yang disebutkan di atas bahwa dapat diketahui betapa pentingnya seorang anak dalam keluarga. Anak laki-laki dan perempuan berdasarkan sistem kekeluargaan menurut hukum adat akan mendapatkan bagiannya masing-masing, harta yang ditinggalkan pun ada yang dapat dibagi dan ada yang tidak dapat dibagi. Hukum adat waris di Indonesia dipengaruhi oleh prinsip garis keturunan. Berkaitan dengan itu, masalah hukum adat waris tidak dapat dipisahkan dengan pembicaraan tentang hukum adat kekeluargaan karena sistem kekeluargaan yang dipergunakan membawa akibat pada penentuan aturan-aturan tentang warisan. Di samping itu, peranan agama yang dianut juga tidak kalah pentingnya dalam penentuan aturan-aturan tentang warisan karena unsur agama adalah salah satu unsur hukum adat. Meskipun hukum adat kekeluargaan di Madura menganut sistem parental, tetapi dalam pelaksanaannya berbeda dengan daerah-daerah lain yang juga memakai sistem parental.

13 Hiksyani Nurkhadijah, "Sistem Pembagian Harta Warisan", Skripsi, (Makasar: Universitas Hasanudin, 2013), hlm. 20.

14 I Gede A.B. Wiranata, 2005, Hukum Adat Indonesia Perkembangannya dari Masa ke Masa, Bandung: PT. Citra Aditya Bakti, hlm. 257-259. 
Pembagian harta warisan haruslah dilakukan sesuai dengan ketentuan masingmasing sistem kekeluargaan tersebut. Apabila tidak dilakukan sesuai dengan sistem yang berlaku, maka hal itu akan mengakibatkan timbulnya konflik antar anggota keluarga. Oleh karena itu, penentuan sistem hukum sangatlah penting untuk menghindari perpecahan dan mencapai suatu keadilan yang diharapkan masing-masing pihak yang terlibat. Dalam sistem hukum adat, anak-anak dari si pewaris merupakan golongan ahli waris yang terpenting dikarenakan mereka pada hakikatnya merupakan satu-satunya golongan ahli waris yang terdekat. Jadi dengan adanya anak-anak, maka kemungkinan anggota keluarga yang lain untuk mejadi ahli waris menjadi tertutup. ${ }^{15}$

Masyarakat Madura Perantauan di Desa Jelbuk, menurut Asnoto berasal dari Sumenep, ${ }^{16}$ mengatakan anak merupakan ahli waris yang paling berhak mendapatkan warisan dari orang tuanya. Hal ini dikarenakan warisan merupakan harta peninggalan yang dialihkan hartanya kepada anak-anaknya sesuai dengan bagiannya masingmasing. Menurut beliau bagian anak laki-laki lebih banyak daripada anak perempuan, biasanya diberikan kepada anak laki-laki tertua, apabila mempunyai anak angkat maka bagian anak angkat mendapatkan 1/4 bagian. Akan tetapi, rumah diberikan kepada anak perempuan karena merupakan tempat berpulangnya "pamolean" saudara lainnya dan ditanggung oleh anak perempuan. Rumah diberikan kepada anak perempuan yang lebih dekat hubungannya dengan orang tuanya. Bentuk harta warisan yang dibagikan berbentuk tanah, rumah dan lain-lain. Di mana proses pembagian atau pengalihan harta warisan tersebut pada saat orang tua sudah tua maka dengan cara ditunjuk (hibah) kepada anak-anaknya dengan bagian tertentu. Apabila dibagikan setelah meninggal dunia lebih cenderung terjadinya pembagian warisan.

Penyelesaian sengketa waris apabila terjadi perselisihan antar ahli waris dilakukan dengan cara musyawarah, diselesaikan secara kekeluargaan dan dapat dibagi ulang dari awal agar tidak terjadi konflik kembali. Namun, apabila perselisihan warisan berupa tanah, maka tanah tersebut dikur kembali, jika pewaris tidak memiliki anak maka yang berhak atas harta warisan adalah istri atau suami yang ditinggalkan dan keponakan. Alasan merantau ke Desa Jelbuk, awalnya sebagai pedagang kain di Desa Jelbuk akhirnya bertemu dengan jodoh dan menikah dan menetap di sini, membeli tanah dan membangun rumah di Desa Jelbuk dan mencari nafkah di sini.

Ada beberapa kasus tidak sama dengan di atas, seperti pewaris memiliki beberapa anak laki-laki dan tidak mempunyai anak perempuan. Berdasarkan hal tersebut menurut hakim dari Sampang, ${ }^{17}$ mengatakan warisan merupakan pengalihan harta terhadap orang yang ditinggalkan seperti istri dan anak, dan ahli waris yang paling berhak mendapatkan harta warisan adalah anak, "siapa lagi yang berhak kalau bukan anak". Menurut beliau dalam pembagian warisan perbandingan bagian anak laki-laki dan anak perempuan adalah $2: 1$ atau bisa $75 \%$ : $25 \%$. Hal ini dikarenakan

15 Soerojo Wingjodipoero, Pengantar dan Azaz-Azaz Hukum Adat, (Bandung: Alumni, 1973), hlm. 219.

16 Hasil wawancara dengan Bapak Asnoto masyarakat Madura Perantauan di Desa Jelbuk Kecamatan Jelbuk Kabupaten Jember pada tanggal 20 Mei 2018.

17 Hasil wawancara Bapak Hakim masyarakat Madura Perantauan di Desa Jelbuk Kecamatan Jelbuk Kabupaten Jember pada tanggal 20 Mei 2018. 
anak laki-laki memiliki tanggung jawab besar di dalam kehidupan dan menanggung istri, anak serta orang tua yang masih hidup. Narasumber di sini memilki tiga anak lakilaki, apabila pewaris tidak memiliki anak maka siapa yang berhak atas harta warisan adalah istri atau suami yang ditinggalkan, saudara terdekat karena sebab titipan atau wasiat.

Bentuk harta warisan yang dibagikan tergantung apa yang dimiliki oleh pewaris, biasanya berupa, tanah, pekarangan dan harta lainnya. Proses pembagian harta warisan pada saat orang tua sudah tua sebelum meninggal dan anak telah dewasa maka dari itu anak-anak dipanggil untuk berkumpul dan membagi bagian mereka sesuai dengan haknya dengan tujuan agar tidak terjadi perselisihan antar keluarga dan adanya keluarga dekat sebagai saksi pada saat pembagian harta tersebut. Rumah biasanya diberikan kepada anak yang tidak keluar merantau atau menetap, sehingga ia berhak atas rumah tersebut dan sebagai pengganti orang tua dan biasanya diberikan kepada anak yang paling muda. Yang terpenting adalah adanya seseorang yang menempati dan mengurus rumah tersebut, semua keluarga senang "bunga kabbi bedeh se ngennengin dulat". Walaupun pembagian warisan dilakukan secara terbuka masih saja terjadi perselisihan antar ahli waris. Menurut beliau, penyelesaian tersebut dapat dilakukan secara kekeluargaan apabila di dengar oleh tetangga lain dianggap kurang enak didengar. Di samping itu, bagian yang tidak terima atau orang yang menggugat maka bagiannya tersebut diwakafkan atau dijual dan hasil penjualan tersebut disumbangkan kepada madrasah. Akan tetapi, jika warisannya berupa tanah yang memiliki luas maka dapat dijadikan sebuah pesantren. Cara tersebut untuk meminimalisir menimbulkan perselisihan kembali. Alasan beliau merantau ke Desa Jelbuk awalnya karena memiliki saudara sepupu di Sukojember, oleh saudara disuruh datang dan akhirnya bertemu dengan jodoh atau istri di Desa Jelbuk akhirnya menikah dan menetap di Jelbuk. Tanah yang ditempati sekarang dan rumah sebagai tempat tinggal mendapatkan warisan dari orang tua istrinya yang merupakan masyarakat Jelbuk sendiri.

Menurut KH. Makdum Bukhori dari Pamekasan, ${ }^{18}$ warisan adalah harta yang diwariskan kepada anak-anaknya dengan bagian tertentu. Ahli waris yang berhak mendapatkan harta warisan adalah anak karena penerus dalam keluarga. Apabila pewaris tidak memiliki anak maka yang berhak atas harta warisan adalah istri atau suami yang ditinggalkan, keponakan atau kerabat dekat yang lain. Bagian anak laki-laki dan perempuan adalah 2: l mengikuti aturan dengan hukum waris Islam sehingga bagian anak laki-laki lebih banyak daripada perempuan. Menurut beliau laki-laki merupakan kepala rumah tangga dan bagiannya biasanya tergantung pewarisnya untuk memberi berapa bagian anaknya tersebut dengan dasar anak laki-laki lebih besar bagiannya. Bagian anak perempuan lebih banyak daripada laki-laki biasanya diberikan kepada anak laki-laki yang lebih tua.

Berbeda dengan kedua narasumber di atas, Menurut KH. Makdum Bukhori, rumah dapat diberikan kepada anak laki-laki maupun anak perempuan yang tinggal

18 Hasil wawancara Bapak KH. Makdum Bukhori masyarakat Madura Perantauan di Desa Jelbuk Kecamatan Jelbuk Kabupaten Jember pada tanggal 20 Mei 2018. 
dan menetap di rumah tersebut dan tidak pergi merantau. Bentuk harta warisan yang dibagikan kepada ahli waris berupa tanah, rumah dan mobil dan benda bergerak lainnya. Proses pembagian harta warisan dilakukan pada saat orang tua sudah lanjut usia maka dengan cara ditunjuk dan terbuka sebelum meninggal dunia, diberi tahu kepada anak-anaknya bagiannya masing-masing. Jika antara ahli waris tidak puas dengan bagiannya maka timbul konflik antara ahli waris sehingga penyelesaiannya dilakukan dengan cara musyawarah tanpa proses ke pengadilan agar semuanya tahu dan memberi pengertian untuk hidup rukun sesama keluarga. Alasan mengapa merantau ke Desa Jelbuk karena memiliki saudara ipar di Desa Jelbuk. Kemudian menikah dan menetap di Jelbuk serta membangun rumah. Akan tetapi, beliau telah berpindah-pindah sebanyak tiga kali dari Tegal Batu, Kacangan dan sekarang menetap di Tenggir Timur serta membangun sebuah pesantren.

Ahli waris yang merupakan kerabat dekat karena hubungan darah atau hubungan perkawinan bisa juga tidak mendapatkan warisan dikarenakan ahli waris tersebut berpindah agama, adanya putusan hakim, yang berkekuatan hukum, berlainan agama, perbudakan dan hilang tanpa berita. ${ }^{19}$ Berdasarkan semua penjelasan narasumber di atas pada masyarakat Madura Perantauan di Desa Jelbuk masih tetap mempertahankan identitas adat istiadat daerah asalnya. Dilihat dari faktor agama, hampir dapat dipastikan semua perantau Madura memilih alternatif strategi tetapi mempertahankan agamanya selama hidup di perantauan. Dalam perspektif antropologis, bagi orang Madura, agama Islam bukan saja sebagai referensi dalam berpikir, bersikap, bertindak dan berperilaku yang bersumber dari nilai-nilai Ilahiyah. Melainkan sudah melekat sebagai salah satu elemen terpenting dalam identitas etniknya. Relasi antara agama Islam dan identitas etnik orang Madura begitu kuat, sehingga merupakan suatu kejanggalan jika orang Madura menganut agama lain selain Islam.

Berbeda dengan masyarakat Jelbuk tentang pembagian warisan sendiri, Menurut Ibu Badi'ah ${ }^{20}$ Kepala Desa Jelbuk mengatakan bahwa warisan adalah harta yang diwariskan kepada anak-anaknya dengan bagian tertentu yang di mana harta tersebut bisa benda bergerak dan tidak bergerak. Adapun bagian anak laki-laki dan anak perempuan adalah sama. Sebagaimana pewarisan adat Madura menganut sistem pewarisan individual sehingga dalam pembagian harta dapat dibagi-bagikan antara para ahli waris sehingga termasuk dalam sistem kekerbatan parental di mana keturunan ditarik melalui silsilah baik dari bapak maupun dari ibu atas harta peninggalan orang tuanya. Hak sama (gelijk gerechtigd), dalam diperlakukan sama oleh orang tuanya dan dalam susunan keluarga menurut keturunan kedua belah pihak, baik pihak bapak maupun pihak ibu (ouder-rechtelijk). Yang berlaku di golongan suku bangsa Jawa dan

19 Diah Tri Setia Ningsih, "Pembagian Warisan Menurut Hukum Waris Islam (Kompilasi Hukum Islam) dengan Hukum Waris Adat Patrilineal”, Skripsi, (Bangkalan : Fakultas Hukum Universitas Trunojoyo, 2006), hlm. 24-27.

20 Hasil wawancara dengan Ibu Badi'ah Kepala Desa Jelbuk Kecamatan Jelbuk Kabupaten Jember pada tanggal 28 Mei 2018. 
Madura berakibat bahwa anak mewarisi dari kedua orangtuanya. Sehingga bagian dari tiap-tiap anak, baik laki-laki dan perempuan pada dasarnya sama.

Menurut beliau, perselisihan antarahli waris sering terjadi, maka sebagai kepala desa dalam menyelesaikan permasalahan tersebut dilakukan upaya mediasi di Kantor Kepala Desa Jelbuk melalui musyawarah. Mediasi tersebut dapat dilakukan secara kekeluargaan, memberi pengertian dan nasehat agar tidak berselisih. Apabila upaya tersebut tidak dapat menyelesaikan maka dikembalikan kepada para pihak yang bersangkutan untuk menyelesaikan perkaranya sendiri. Salah satu pihak yang berselisih melaporkan perkara ke Polsek Jelbuk dan kemudian ditindaklanjuti apabila para pihak menghendaki ke proses hukum (pengadilan). Tetapi itu tidak pernah terjadi penyelesaian sampai ke tahap pengadilan, selama ini yang terjadi penyelesaian sampai aparat desa saja. Apabila ada yang berperkara atau berselisih memperebutkan hak waris di lingkungan masyarakat mendapatkan sanksi sosial apabila ada pihak yang memiliki kepentingan pribadi, semisal tanah tersebut bukan haknya akan tetapi menggugat untuk menjadi haknya maka masyarakat tidak suka terhadapnya.

Proses pemberian harta warisan biasanya dilakukan sebelum pewaris meninggal dan setelah pewaris meninggal, "jika ada bapak atau ibu tanya bagiannya supaya tidak terjadi konflik". Sama halnya dengan tradisi di daerah Pamekasan dapat digambarkan dalam beberapa variasi, berkaitan dengan waktu pelaksanaan pembagian dapat dipetakan menjadi tiga fase, diantaranya pembagian dilakukan saat pewaris masih hidup, dilakukan setelah pewaris meninggal dan dilakukan sebelum dan sesudah pewaris meninggal baik karena belum sempat membagi sama sekali maupun karena sudah dibagi saat masih hidup. ${ }^{21}$ Menurut Saha, ${ }^{22}$ sama halnya dengan narasumber di atas di mana anak laki-laki dan anak perempuan dalam masyarakat Jelbuk sendiri adalah sama dan yang berhak atas warisan tersebut adalah anak kandung pewaris karena anak yang lebih berhak daripada keluarga yang lainnya. Bagian anak sama agar dipandang adil dan tidak membeda-bedakan, sehingga anaklah yang berhak atas harta warisan tersebut. Kadang ada ahli waris jika tidak mendapatkan harta warisan karena hal tertentu maka mendapatkan "sabab" yaitu barokah dari orang tua karena barokah menjadikan hidup lebih berkah.

Menurut Kushaeri Kepala Dusun Tenggir Timur Desa Jelbuk ${ }^{23}$, mengatakan bahwa warisan adalah pembagian harta peninggalan yang dialihkan hartanya kepada anak-anaknya sesuai dengan bagian tertentu yang tergantung pewaris mengenai pembagiannya. Di mana pembagian anak laki-laki dan anak perempuan adalah sama agar tidak terjadi konflik antara para ahli waris, yang berhak harta warisan tersebut jika pewaris meninggal adalah suami/istri yang ditinggalkan dan anak-anaknya. Bentuk harta warisan berbentuk ladang, tanah dan harta lainnya, yang dibagikan pada saat

21 Maimun Namawi, Kontekstualisasi Hukum Waris Islam dalam Tradisi Masyarakat Pamekasan Madura Perspektif Maslahah Najm Al-Din Al-Tufi, Jurnal Hukum, (Pamekasan : IAIN Madura, 2015).

22 Hasil wawancara dengan Bapak Saha tokoh masyarakat di Desa Jelbuk Kecamatan Jelbuk Kabupaten Jember pada tanggal 28 Mei 2018.

23 Hasil wawancara dengan Bapak Kusaeri Kepala Dusun Tenggir Timur Desa Jelbuk Kecamatan Jelbuk Kabupaten Jember pada tanggal 20 Mei 2018. 
belum meninggal. Pembagiannya di depan para ahli warisnya agar tidak menimbulkan prasangka yang tidak diinginkan atau pilih kasih antara ahli waris. Walaupun demikian, masih ada warga masyarakat yang berselisih mengenai bagian yang telah diterima maka proses penyelesaiannya diselesaikan secara kekeluargaan. Namun, apabila belum terselesaikan maka penyelesaian di tingkat RT, jika belum terselesaikan juga maka RT melapor kepada Kepala Kampung sebagai penengah dalam menyelesaikan permasalahan antara para pihak. Apabila tidak selesai maka ditindaklanjuti ke Kantor Kepala Desa yaitu kepala desa yang menjadi mediator, terakhir jika belum bisa diselesaikan biasanya salah satu melapor ke Polsek terdekat dan bisa saja sampai dengan tahap Pengadilan. Akan tetapi, masyarakat belum ada yang berperkara sampai pengadilan. Pihak Polsek menyarankan agar perselisihan warisan semacam ini diselesaikan secara kekeluargaan atau tingkat desa, apabila berselisih mengakibatkan merenggangnya hubungan antara saudara.

Pembagian harta warisan pada masyarakat Madura Perantauan tidak sama halnya dengan masyarakat asli Desa Jelbuk. Di mana masyarakat Madura Perantauan bagian anak laki-laki lebih besar daripada anak perempuan yaitu $2: 1$, sedangkan pada masyarakat Desa Jelbuk bagian anak laki-laki dan anak perempuan mendapatkan bagian yang sama. Masyarakat Madura Perantauan masih mempertahankan kebiasaan, tradisi atau kebudayaan mereka dengan berpedoman pada agama Islam. Walaupun tetap mempertahankan tradisi asal mereka mengenai pembagian warisan, tetapi mampu beradaptasi dalam kehidupan masyarakat sekitar seperti dalam kegiatan keagamaan dalam memperingati hari-hari penting agama Islam. Salah satu contohnya selama bulan Asyuro mereka membuat selamatan jenang suro, selama bulan Safar diadakanlah selamatan jenang sapar dan di bulan Maulud mereka memperingati dengan selamatan maulud.

Sistem perkawinan di Madura menganut pola matrilokal, artinya perempuan yang telah menikah akan tetap tinggal di rumah atau pekarangan milik orang tuanya. Sementara laki-laki yang telah menikah akan pindah ke rumah atau pekarangan istrinya atau mertuanya. Akan tetapi, hal ini tidak berlaku mutlak untuk mayoritas pasangan suami istri suku Madura sebab sebagian atau beberapa pasangan ada yang memilih pola natalokal atau membangun rumah sendiri. Selama beberapa waktu setelah menikah, pasangan suami-istri akan bertempat tinggal di rumah istri atau mertua. Pola residensi matrilokal inilah yang kemudian melahirkan atau menghasilkan pola hunian tanian lanjheng. ${ }^{24}$ Meskipun di Madura menganut pola residensi matrilokal, akan tetapi garis keturunan tidak menggunakan sistem kekerabatan matrilineal, melainkan menggunakan sistem bilateral yang tidak menekankan pada garis bapak maupun ibu. Garis keturunan ini diletakkan secara seimbang pada garis ayah (patrilineal) dan garis ibu (matrilineal). Kemudian pada aturan pembagian harta warisan, masyarakat Madura membagi harta warisan ketika orang tua masih hidup yaitu melalui hibah. Umumnya,

24 Masthuriyah Sa'dan, Tradisi Perkawinan Matrilokal Madura (Akulturasi Adat dan Hukum Islam), Jurnal Hukum, (Yogyakarta: UIN Sunan Kalijaga Vol.14, 2016), hlm. 131. 
anak perempuan mendapat harta warisan seperti rumah dan tanah pekarangan dan tidak boleh dijual kepada siapapun yang disebut dengan sangkolan. ${ }^{25}$

Sebagaimana dikatakan oleh Hazairin, bahwa hukum waris adat mempunyai ciri dan corak tersendiri dengan membentuk suatu kekerabatan yang sistem keturunannya meliputi patrilineal, matrilineal, dan parental atau bilateral. Walaupun dalam kekerabatan yang sama belum tentu berlaku sistem kewarisan yang sama. Seperti halnya masyarakat Madura Perantauan di Desa Jelbuk dengan masyarakat di Desa Patoan Daya mengenai pelaksanaan pembagian warisan pun berbeda meskipun dengan sistem keturunan parental atau bilateral. Begitu pula, pada masyarakat Jelbuk sendiri yang mayoritas bersuku Madura akan tetapi dalam pelaksaan pembagian warisannya pun berbeda.

\section{KESIMPULAN}

Berdasarkan beberapa pembahasan di atas, maka dapat diambil suatu kesimpulan yaitu bahwa sistem pewarisan menurut hukum adat Madura Perantauan di Desa Jelbuk dengan sistem pewarisan hukum adat di Desa Potoan Daya menggunakan sistem pewarisan yang sama yaitu sistem pewarisan individual. Di mana setiap ahli waris mendapatkan haknya secara individu dan dengan sistem keturunan atau kekerabatan parental yaitu sistem pewarisan yang ditarik dari garis keturunan bapak maupun ibu. Sistem pewarisan hukum adat Madura Perantauan di Desa Jelbuk menggunakan sistem pewarisan individual di mana setiap ahli waris berhak atas harta warisan dari kedua orang tuanya. Sistem yang demikian telah diterapkan secara turun-temurun. Bagian anak laki-laki dan perempuan menurut hukum adat Madura Perantauan di Desa Jelbuk mendapatkan bagian 2 : l. Namun, sebuah rumah "patobin" diberikan kepada anak perempuan sebagai tempat pulangnya "pamolean" sanak saudara yang diberikan secara sukarela oleh orang tua atau pewaris. Jika pewaris tidak memiliki anak perempuan maka diberikan kepada anak laki-laki yang menetap dan tidak pergi untuk merantau. Berbeda dengan sistem pewarisan masyarakat Jelbuk, di mana bagian anak laki-laki dan perempuan terhadap harta warisan adalah 1 : l agar tidak menimbulkan perselisihan warisan.

Adapun saran terkait hal tersebut yaitu pembagian harta warisan pada Madura Perantauan di Desa Jelbuk seharusnya tidak membedakan antara ahli waris anak lakilaki dan anak perempuan atau memiliki persamaan hak atas harta warisan dari kedua orangtuanya. Masyarakat Madura Perantauan di Desa Jelbuk apabila pembagian warisan tersebut tidak adil hendaknya melakukan musyawarah agar dapat mencapai rasa keadilan dan sistem pewarisan tersebut dianggap adil. Dengan demikian, secara otomatis ahli waris harus menerima dan tetap mempertahankan sistem pewarisan hukum adat Madura Perantauan. Pembagian warisan pada masyarakat Madura Perantauan di Desa Jelbuk apabila terjadi permasalahan warisan sebaiknya ahli waris tidak mempersalahkan karena pentingnya hidup rukun dalam keluarga.

25 Ibid, hlm. 136. 


\section{DAFTAR PUSTAKA}

Arianto, Krishna Henry. 2018. Tradisi Carok pada Masyarakat Adat Madura, http://www.esaunggul.ac.id, diakses pada tanggal 26 Mei 2018 Pukul 15.00 WIB.

Fath, Kutwa. 2006. Pamekasan dalam Sejarah. Pamekasan: Pemerintah Kabupaten Pamekasan.

Hadikusuma, Hilman. 2003. Pengantar Ilmu Hukum Adat Indonesia. Bandung: Mandar Maju. Haries, Akhmad. 2014. Analisis Tentang Studi Komparatif antara Hukum Kewarisan Islam dan Hukum Kewarisan Adat. Jurnal Hukum. (Samarinda: STAIN Samarinda, Vol 6 No 2, 2014).

Ibrahim, Ahmad. 2010. Menyelesaikan Sengketa Pembagian Harta Warisan Melalui Peran Kepala Desa. Jurnal Hukum. (Universitas Gorontalo, 2010).

Komari. 2015. Eksistensi Hukum Waris di Indonesia: antara Adat dan Syariat. Jurnal Hukum. (Mahkamah Agung Republik Indonesia Vol. 17 No. 2, 2015).

Namawi, Maimun. 2015. Kontekstualisasi Hukum Waris Islam dalam Tradisi Masyarakat Pamekasan Madura Perspektif Maslahah Najm Al-Din Al-Tufi. Jurnal Hukum. Pamekasan: IAIN Madura.

Ningsih, Diah Trsi Setia. 2006. Pembagian Warisan Menurut Hukum Waris Islam (Kompilasi Hukum Islam) Dengan Hukum Waris Adat Patrilineal. Skripsi. Bangkalan: Fakultas Hukum Universitas Trunojoyo.

Nurkhadijah, Hiksyani. 2013. Sistem Pembagian Harta Warisan. Skripsi. Makasar: Universitas Hasanudin.

Sari, Putri Kurnia. 2012. Pembagian Warisan dalam Budaya Poligini (Studi Kasus pada Komunitas Madura di Boto Putih, Surabaya). Jurnal Hukum. (Surabaya: Unair, Vol.1 No.1, 2012).

Sa'dan, Masthuriyah. 2016. Tradisi Perkawinan Matrilokal Madura (Akulturasi Adat dan Hukum Islam). Jurnal Hukum. (Yogyakarta: UIN Sunan Kalijaga Vol.14, 2016).

Sudaryanto, Agus. 2010. Aspek Ontologi Pembagian Waris Dalam Hukum Islam Dan Hukum Adat Jawa. Jurnal Hukum. (Mimbar Hukum Volume 22, Nomor 3, 2010).

Wingjodipoero, Soerojo. 1973. Pengantar dan Azaz-AzazHukum Adat. Bandung: Alumni.

Wiranata, I Gede A.B. 2005. Hukum Adat Indonesia Perkembangannya dari Masa ke Masa. Bandung: PT. Citra Aditya Bakti.

Wiyata, Latief. 2013. Mencari Madura. Jakarta: Bidik-Phonesis Publishing. 
448 | Studi Komparasi Hak Waris dalam Hukum Adat dan Islam di Masyarakat Madura Perantauan Desa Jelbuk, ...

This page is intentionally left blank 